\title{
Kraton Buton Sebagai Sumber Sejarah Lokal dalam Pembelajaran Sejarah
}

\author{
Ali Guntur, Abdul Syukur, Umasih \\ Universitas Pattimura Ambon \\ aliguntur90@gmail.com
}

\begin{abstract}
The focus of this research is Kraton Buton as a source of local history in the learning of history. The purpose of this research is to know whether Kraton Buton is utilized as a source of learning local history. as a historical heritage, Kraton Buton has a rich historical source for local history as part of Indonesia's national history, but in fact historical sites such as Kraton Buton can not be utilized well, because as a source of learning it still focuses on textbooks. Data search is done through observation, interview and documentation. The methodology used is qualitative with Miles and Huberman interactive model analysis approach, data reduction, data presentation, and conclusion, to track and uncover the facts. The result of this research is Kraton Buton as the former government center of Buton Sultanate and as the center of Buton culture keeps unique and interesting relics. The management effort of the palace area in 2003 by the Baubau City government through the Tourism Department opened the space for Kraton Buton to be used as a source of local history by the public widely including for scientific research purposes. The opening of Kraton Buton also encourages the role of history teacher to utilize Kraton Buton as a source of local history in learning history in class.
\end{abstract}

Keywords: Kraton Buton, local history source, and history learning

\begin{abstract}
Abstrak: Fokus penelitian ini adalah Kraton Buton sebagai sumber sejarah lokal dalam pembelajaran sejarah. Tujuan penelitian ini adalah untuk mengetahui apakah Kraton Buton dimaanfaatkan sebagai sumber belajar sejarah lokal. dikarenakan sebagai sebuah peninggalan sejarah, Kraton Buton memiliki sumber sejarah yang kaya bagi sejarah lokal sebagai bagian sejarah nasional Indonesia, akan tetapi pada kenyataannya situs sejarah seperti Kraton Buton belum dapat dimanfaatkan dengan baik, karena sebagai sumber belajar masih memusatkan pada buku-buku teks. Pencarian data dilakukan melalui observasi, wawancara dan dokumentasi. Metodologi yang digunakan adalah kualitatif dengan pendekatan model analisis interaktif Miles dan Huberman yaitu reduksi data, penyajian data, dan penarikan kesimpulan, untuk menelusuri dan mengungkap fakta tersebut. Hasil penelitian ini adalah Kraton Buton sebagai bekas pusat pemerintahan Kesultanan Buton dan sebagai pusat kebudayaan Buton menyimpan peninggalanpeningalan yang unik dan menarik. Upaya pengelolaan wilayah kraton pada tahun 2003 oleh pemerintah Kota Baubau melalui Dinas Pariwisata membuka ruang bagi Kraton Buton untuk dijadikan sebagai sumber sejarah lokal oleh masyarakat secara luas termasuk untuk keperluan penelitian karya ilmiah. Terbukanya Kraton Buton ini pula mendorong peran guru sejarah untuk memanfaatkan Kraton Buton sebagai sumber sejarah lokal dalam pembelajaran sejarah di kelas.
\end{abstract}

Kata Kunci: Kraton Buton, sumber sejarah lokal, dan pembelajaran sejarah 


\section{PENDAHULUAN}

Pembelajaran sejarah secara umum dinilai dan dianggap oleh siswa tidak terlalu penting. Karena guru sejarah hanya menekankan kepada siswa untuk menghafal suatu informasi masa lalu seperti siapa, kapan, dan dimana peristiwa itu terjadi, tanpa melakukan rancangan pembelajaran sejarah yang lebih mengarah untuk menganalisis suatu informasi masa lalu tersebut. Karena dengan belajar sejarah siswa akan lebih mengenal identitas dirinya, lingkunganya serta bangsa dan negaranya (Gunning, 1978: 179-180). Namun untuk mencapai hal itu, perlu adanya kreatifitas guru dalam mencari dan menggali sumbersumber sejarah untuk dirancang dan disampaikan dalam pembelajaran sejarah di kelas. Widja (2012; 23) menyatakan bahwa pembelajaran sejarah adalah perpaduan antara aktivitas belajar dan mengajar yang didalamnya mempelajari tentang peristiwa masa lalu yang erat kaitannya dengan masa kini.

Kenyataan pembelajaran sejarah di Sekolah Menengah Atas (SMA) yang ada di Kota Baubau, sudah berjalan dengan baik dan efektif sesuai dengan tujuan pembelajaran sejarah yang ingin dicapai yaitu untuk mencerdaskan dan membentuk karakter bangsa serta memberikan nilainilai moral terhadap generasi masa kini. Namun masih ada kekurangannya, yakni keengganan guru sejarah menggunakan sumbersumber sejarah lokal dalam pembelajaran sejarah. Kondisi ini juga didukung oleh kurangnya kreatifitas guru untuk memanfaatkan sumber sejarah lokal Kraton Buton yang tersedia banyak untuk di pakai dan dipelajari. 
Kraton Buton merupakan pusat kekuasaan Kesultanan Buton yang memiliki sejarah yang sangat panjang. Eksistensinya pun menjadi salah satu faktor terpenting dalam menandai pertumbuhan dan perkembangan kebudayaan masyarakat Buton, sehingga Kraton Buton menjadi pusat kebudayaan masyarakat Buton yang tetap eksis hingga sekarang ini. Peralihan eksistensi Kraton Buton sebagai salah satu wilayah kekuasaan politik kesultanan ditandai ketika Sultan terakhir Muh. Falihi bertemu dengan Presiden Soekarno pada tahun 1960 di Makasar. Sehingga sejak pertemuan ini Kesultanan Buton hanya bersifat sebagai pusat kebudayaan bagi orang Buton dan hanya melakukan kegiatan pelestarian budaya, tanpa memiliki wilayah kekuasaan seperti sebelumnya.

Keraton Buton menjadi salah satu tempat bersejarah yang paling penting di kota Baubau dan sekitarnya. Hal ini dikarenakan Keraton Buton merupakan salah satu bukti dan saksi sejarah yang terjadi di wilayah ini. Sebagai sumber sejarah Kerajaan Buton meliputi jejak sejarah dari transisi masuknya Islam ke Indonesia, serta saksi sejarah panjang penjajahan di Indonesia (Suryanegara, 2008; 102). Peninggalanpeninggalan berupa bangunan yang telah lama berdiri, serta benda-benda yang merupakan saksi sejarah keberlangsungan Kerajaan Buton.

Peninggalan-peninggalan Kesultanan Buton merupakan bukti empiris yang harus dimanfaatkan oleh guru sebagai sumber sejarah lokal dalam pembelajaran sejarah. Mengingat pentingnya sejarah lokal sebagai bagian dalam memahami sejarah nasional (Kartodirjo, 2014; 84), sehingga kinerja dan kreatifitas guru sejarah menjadi faktor yang paling menentukan untuk mewujudkan tujuan tersebut. Hal ini, akan sangat 
bermanfaat bagi perkembangan kognitif historis siswa dalam mengetahui lingkungannya secara baik. Selain bukti empiris tersebut yang akan dijadikan sebagai sumber sejarah lokal dalam pembelajaran sejarah guru juga harus memanfaatkan sumber-sumber tertulis seperti buku, dokumen dan lain-lain dalam pembelajaran sejarah agar lebih menyenangkan dan berwawasan.

Berdasarkan penjelasan di atas maka Kraton Buton sebagai sumber sejarah lokal mempunyai arti yang sangat penting dalam pembelajaran sejarah, yakni pertama, meningkatkan efektifitas pembelajaran sejarah di Sekolah Menengah Atas (SMA) yang ada di Kota Baubau. Kedua, memudahkan guru sejarah dalam menyampaikan materi pelajaran sejarah secara bervariasi. Ketiga, dengan mengetahui sumber sejarah lokal, siswa akan lebih terbentuk kesadarannya untuk belajar sejarah. Dan keempat, identitas kelokalan Buton lebih terekspos dengan baik dalam pembelajaran sejarah.

\section{METODE}

Metodologi penelitian yang digunakan adalah penelitian kualitatif dengan pendekatan deskritif analisis. Teknik dan prosedur pengumpulan data pada penelitian ini yakni, observasi atau pengamatan langsung, wawancara dan dokumentasi. Wawancara dengan informan atau narasumber yang akan di wawancarai terkait dengan tema penelitian ini adalah pihak pengelola (Dinas Pariwisata), masyarakat adat Kraton Buton, kepala sekolah, guru sejarah, dan siswa SMA Kota Baubau. Dokumentasi yang dilakukan oleh peneliti menggunakan dokumentasi berupa pengambilan foto-foto, rekaman, catatan dan lain-lain. Setelah data 
dikumpulkan, selanjutnya dianalisis dengan menerapkan model analisis interaktif yaitu reduksi data, penyajian data, dan penarikan kesimpulan atau verifikasi.

\section{HASIL TEMUAN}

Hasil penelitian ini adalah pertama, Kraton Buton sebagai pusat kekuasaan Kesultanan Buton banyak menyimpan peninggalanpeninggalan sejarah yang dapat dijadikan sebagai sumber sejarah lokal. Saat ini Keraton Buton dijadikan sabagai salah satu tempat wisata bersejarah di kota Baubau, berdasarkan peraturan pemerintah kota Baubau. Sebagai tempat bersejarah yang memiliki peninggalanpeninggalan yang unik dan menarik, Keraton Buton memiliki potensial untuk digunakan sebagai sumber belajar sejarah lokal. Keraton Buton menyimpan jejak sejarah yang penting bagi masyarakat yang berada disekitarnya. Jejak sejarah dari awal berdirinya Kerajaan Buton hingga runtuhnya kerajaan tersebut, sejarah kerajaan Buton merupakan sejarah lokal yang dimiliki masyarakat Buton sebagai bagian dari kesatuan sejarah nasional Indonesia. Kerajaan Buton sebagai salah satu kerajaan islam di Indonesia, tentunya menjadi bagian penting sebagai salah satu sumber yang berkaitan dengan pemahaman sejarah Indonesia masa islam.

Jejak sejarah lokal yang terekam dalam Keraton Buton dapat memberikan pemahaman lebih tentang sejarah lokal. Hal tersebut selain dikarenakan peninggalan berupa komplek istana, melainkan juga banyak peninggalan sejarah lainnya yang dapat dieksplorasi baik oleh guru maupun siswa, serta masyarakat sekitar agar dapat memahami sejarahnya. Peninggalan yang terdapat di Kraton Buton yakni, Benteng 
Keraton Buton yang merupakan peninggalan sejarah yang tidak hanya bermakna dari fungsinya sebagai pertahanan terakhir Keraton Buton, juga dapat dijadikan sebagai sumber sejarah mengenai proses pembangunan dan material pembangunannya. Peninggalan-peninggalan sejarah lainnya yang juga melengkapi jejak sejarah kerajaan Buton seperti Batu Wolio, Batu Popaua, Baruga, masjid kuno, makam-makam sultan dan lainnya. Merupakan peninggalan yang dapat memberikan pemahaman lebih tentang situasi dan kondisi pada masa islam, serta masa penjajahan di Indonesia.

Kedua, pengelolaan Kraton Buton yang dilakukan oleh Dinas Pariwisata telah memudahkan para pengunjung dan peneliti untuk memanfaatkan lingkungan kraton sebagai sumber penelitian untuk karya ilmiah maupun digunakan sebagai tempat wisata. Setelah dikeluarkan peraturan pemerintah Kota Bau No. 105 tahun 2003, Kraton Buton diresmikan sebagai salah satu tempat wisata bersejarah. Pemerintah Kota Baubau melalui Dinas Pariwisata menjadikannya sebagai salah satu tempat wisata sejarah sehingga peninggalan-peninggalan sejarah Kesultanan Buton yang ada dilingkungan Kraton Buton menjadi tanggung jawab pemerintah. Pemerintah Kota Baubau mulai melakukan pemugaran dan perbaikan terhadap peninggalan-peninggalan Kraton Buton agar dapat diminati oleh para wisatawan lokal maupun mancanegara. Dinas Pariwisata Kota Baubau, yang berhasil mewujudkan Kraton Buton sebagai tempat wisata, sekaligus tempat yang dapat menyajikan pengalaman bersejarah. Hal tersebutlah yang menjadikan Kraton Buton saat ini tidak hanya dikunjungi untuk kepentingan wisata, melainkan juga dijadikan lokasi penelitian ilmiah. Perkembangan dan 
pertumbuhan Kraton Buton dibawah pengawasan Dinas Pariwisata sangat luar biasa karena Kraton Buton yang dalam anggapan historiografi Indonesia sebagai daerah yang bekerja sama dengan pihak Belanda dan dicap sebagai penghianat akhirnya dilupakan oleh masyarakat. Hal ini akibat dari pengelolaan yang dilakukan oleh pemerintah setempat sehingga menimbulkan ketertarikan salah satu sejarawan Indonesia Prof. Dr. Susanto Zuhdi untuk menulis buku yang berjudul "Sejarah Buton Yang Terabaikan, Labu Rope Labu Wana". Buku ini mengungkap dengan secara jelas tentang posisi Kraton Buton yang terhempit dua hegemoni besar Kerajaan Gowa dan Kerajaan Ternate, sehingga Kesultanan Buton berusaha keluar dari hegemoni itu dan bekerjasama dengan kompeni menurut bahasa Buton. Tulisan Prof. Dr. Susanto Zuhdi ini sangat baik untuk dijadikan sumber sejarah lokal oleh guru sejarah dan siswa.

Ketiga, guru sejarah SMA di Kota Baubau sudah memanfaatkan Kraton Buton sebagai sumber sejarah lokal dalam bentuk kunjungan maupun maupun pemberian tugas kepada siswa serta pemanfaatan sumber tertulis yang dikorelasikan dengan sumber sejarah nasional di kelas. Siswa hampir setiap hari ditemukan dilingkungan Kraton Buton dalam memanfaatkan peninggalan-peninggalan sejarah kesultanan tersebut. Ada yang ditemukan berupa kelompok siswa dengan pengawasan guru sejarah dan guru-guru yang lain, ada juga yang ditemukan siswa hanya berkelompok 4 sampai dengan 5 orang tanpa pengawasan guru. Siswa cukup aktif dalam mengamati dalam meneliti setiap benteng kraton, guru sejarah yang membawa siswa juga menyampaikan arahan-arahan positif terkait dengan pemanfaatan kraton 
bahkan guru sejarah lebih terlihat aktif dalam memanfaatkan Kraton Buton sebagai sumber sejarah lokal. Kunjungan guru sejarah dan siswa di museum Kraton Buton ialah untuk melihat benda-benda antik seperti ruang pertemuan sultan, foto-foto peninggalan Kesultanan Buton, alatalat musik tradisional, dan alat-alat pelengkap keseharian sultan seperti kursi santai, tempat makan, tempat minum dan lain-lain. Pemahaman terhadap benda-benda yang terdapat di dalam museum ini ialah untuk menambah wawasan sejarah dan budaya masa lalu bagi guru sejarah dan siswa agar kecintaan terhadap taah Buton semakin tinggi di masa mendatang.

Keempat, respon siswa terhadap pembelajaran sejarah lokal terkait sejarah Kraton Buton di kelas cukup baik secara keseluruhan. Biasanya respon siswa yang baik terhadap pembelajaran sejarah lokal karena dipengaruhi oleh daya tarik belajar siswa yang tinggi terhadap pembelajaran sejarah di kelas. Pemberian informasi mengenai sejarah Kesultanan Buton bagi siswa SMA di Kota Baubau akan membentuk kesadaran siswa itu sendiri untuk menyukai pembelajaran sejarah. Karena sejarah Kesultanan Buton tidak kalah menarik dari sejarah daerah-daerah lain yang ada di Indonesia.

\section{PEMBAHASAN HASIL TEMUAN}

Menurut Rifai (2011:36) bahwa manusia menciptakan Tradisi, budaya, adat istiadat. Dalam kehidupan sosial, manusia berusaha mempertaruhkan, mempertahankan identitas dan kepribadiannya. Pendidikan ikut berperan serta dalam mengelola budaya dan mengembangkan kepribadian manusia secara utuh dan baik. Identitas 
dan kepribadian itu tercermin pula dalam Latar belakang sejarah Kraton Buton yang menunjukan bahwa nenek moyang terdahulu di Kraton Buton dalam membangun suatu wilayah atau negara harus berlandaskan pada niat yang jujur dan adil, mengutamakan rasa solidaritas yang tinggi serta kerjasama yang baik antara pejabat kraton dan masyarakat. Warisan kraton Buton ini merupakan peradaban yang sangat bernilai tinggi bagi generasinya.

Upaya Dinas Pariwisata dalam mengelola Kraton Buton merupakan langkah yang tepat, karena tanpa pengelolaan yang dilakukan tersebut, Kraton Buton tidak akan menjadi tempat wisata sejarah yang menarik pada saat ini dan juga Kraton Buton tidak akan dikenal oleh dunia dan mendapatkan beberapa penghargaan seperti rekor MURI tahun 2006 sebagai benteng terluas di Indonesia dan menjadi tuan rumah pergelaran festival kraton se-Nusantara tahun 2012.

Pertumbuhan dan perkembangan kraton Buton melalui Dinas Pariwisata juga berdampak positif bagi generasi Buton untuk menjadikan Kraton Buton sebagai sumber sejarah lokal bagi Peneliti dari dalam maupun dari luar masyarakat Buton. Bukti autentik dari dampak positif tersebut ialah ketertarikan Prof. Dr. Susanto Zuhdi dalam menulis bukunya yang berjudul "Sejarah Buton Yang Terabaikan" yang diterbitkan pada tahun 2010.

Perkembangan lain ialah Kraton Buton telah membuka peluang bagi semua orang untuk menikmati situs-situs sejarah peningggalan eks kesultanan Buton secara langsung, yang sebelumnya tertutup bagi semua orang. Saat ini kraton Buton telah banyak dikunjungi oleh para pewisata dalam negeri maupun luar negeri dan banyak pengunjung yang 
memanfaatkan kraton Buton sebagai pemenuhan penulisan karya ilmiahnya.

Guru adalah pendidik profesional dengan tugas utama mendidik, mengajar, membimbing, mengarahkan, melatih, menilai, dan mengevaluasi peserta didik pada pendidikan formal, pendidikan dasar, dan pendidikan menengah. Sebagai pendidik professional, guru tentunya mempunyai keahlian yang multifungsi dalam menjalankan tugasnya. Oleh karena itu, kinerja guru merupakan kemampuan dan keberhasilan guru dalam melaksanakan tugas-tugas pembelajaran. Kinerja guru dipengaruhi oleh berbagai faktor. Faktor-faktor yang mempengaruhi kinerja guru antara lain: sikap mental (motivasi kerja, disiplin kerja, etika kerja), pendidikan, keterampilan, manajemen kepemimpinan, tingkat penghasilan, gaji dan kesehatan, jaminan sosial, iklim kerja, sarana prasarana, teknologi dan kesempatan berprestasi (Supardi, 2016:19).

Peran guru sejarah dalam memanfaatkan Kraton Buton sebagai sumber sejarah lokal merupakan suatu hal yang sangat penting untuk dilakukan demi membangun pengetahuan peserta didik yang memiliki wawasan masa lalu yang komprehensif yaitu pengetahuan sejarah secara nasional dan secara lokal. Kraton Buton merupakan sumber sejarah lokal yang menyimpan banyak peninggalan sejarah maupun nilai-nilai budaya lokal yang sangat berharga. Menurut Koentjaraningrat 2009:144), kebudayaan adalah keseluruhan sistem gagasan, tindakan dan hasil karya manusia dalam kehidupan masyarakat yang dijadikan milik diri manusia dengan belajar. Hal ini dapat dirumuskan bahwa lahirnya budaya karena atas gagasan dan tindakan manusia yang diperoleh karena belajar. Oleh karena itu, pembentukan pengetahuan siswa terhadap budaya lokalnya 
dalam proses pembelajaran, siswa akan mampu menerapkan nilai-nilai budaya lokal dalam kehidupan sosialnya.

Pengetahuan siswa yang dibangun oleh guru sejarah mengenai Kraton Buton sebagai sumber sejarah lokal, bukan untuk mengembalikan kehidupan siswa pada masa lalunya. Akan tetapi, dapat membuat siswa untuk berpikir dalam memetakan masa lalu itu sebagai acuan bagi masa depannya. Hal tersebut bisa diperoleh melalui belajar untuk memahami konsepsi terhadap masa lalu berdasarkan pengalaman atau dengan proses pembelajaran yang dibangun secara tersistematis oleh guru sejarah.

Pembelajaran sejarah lokal Kraton Buton yang dilakukan oleh guru sejarah ialah hasil dari rancangan dan desain yang dilakukan oleh guru dalam menyisipkan atau mengintegrasikan sejarah lokal dalam sejarah nasional. Karena materi sejarah Kesultanan Buton tidak termuat secara khusus dalam kurikulum pembelajaran sejarah. Hal ini tentunya membutuhkan kreatifitas guru sejarah dalam merancang pembelajaran sejarah di sekolah dengan memanfaatkan sejarah lokalnya. Guru sejarah di Sekolah Menengah Atas (SMA) yang ada di Kota Baubau, belum secara keseluruhan memanfaatkan Kraton Buton sebagai sumber sejarah lokal. Hal ini hanya terjadi pada sekolah-sekolah yang berstatus negeri. Namun sebagian besar guru sejarah yang ada di Sekolah Menengah Atas (SMA) yang ada di Kota Baubau sudah memanfaatkan Kraton Buton sebagai sejarah lokal dengan baik dan benar. Pemanfaatan Kraton Buton sebagai sumber sejarah lokal dapat dilakukan dalam 2 cara yakni Pertama, guru memanfaatkan sumber-sumber tertulis dalam pembelajaran sejarah, misalnya buku-buku sejarah yang mempunyai hubungan dengan Kraton 
Buton, arsip-arsip Kraton Buton yang tersimpan di perpustakaan pribadi A. M. Zahari, serta karya-karya ilmiah menyangkut dengan Kraton Buton. Kedua, guru memanfaatkan bukti fisik seperti kamali, masjid kuba, baruga, tiang bendera kesultanan, kuburan sultan dan kuburan kuno lainnya, benteng kraton, dan lain-lain. Bukti-bukti fisik tersebut masih berdiri kokoh dan terpelihara dengan baik dalam kraton hingga sekarang. Kraton Buton dengan latarbelakang sejarah yang sangat panjang telah meninggalkan banyak bukti-bukti sejarah yang unik dan menarik untuk dipelajari. Pemanfaatan guru sejarah terhadap sumber sejarah lokal Kraton Buton diharapkan dapat membangun kognitif serta mentalitas siswa yang ada di SMA Kota Baubau dalam memahami dan mengimplementasikannya dalam kehidupan sehari-hari. Siswa juga dapat mengambil dan mempelajari makna dan nilai-nilai setiap bukti-bukti sejarah yang dipelajarinya itu. Karena kearifan lokal Kraton Buton merupakan warisan terbaik yang ada di tanah Buton, menyimpan nilainilai sejarah yang sangat tinggi. Namun fenomena yang terjadi sekarang ini belum secara sepenuhnya generasi terutama anak-anak pelajar memanfaatkan Kraton Buton dengan baik. kebanyakan dari generasi maupun anak-anak pelajar memanfaatkan Kraton Buton sebagai tempat refreshing atau hanya sekedar tempat untuk berfoto-foto. Hal ini akan menjadi kekhawatiran jika pemerintah maupun lembaga pendidikan formal tidak sering memberikan penyuluhan maupun pemahaman terhadap generasinya.

Peran guru dalam memotifasi sangat dominan untuk menimbulkan efek terhadap respon siswa dalam pembelajaran. Menurut Wina Sanjaya dalam Al-tabany (2014:88), mengemukakan bahwa guru harus mampu 
membuat siswa merangsang dan dapat mengajak siswa untuk berpikir memecahkan masalah serta mampu membawa siswa pada persoalan yang mengandung teka-teki, agar siswa mampu berpikir kreatif.

SMA Kota Baubau mempunyai siswa yang memiliki karakteristik yang hampir sama yaitu siswa yang berbudaya dan beragama yang baik. peran masyarakat dalam lingkungan masih menjadi faktor utama dalam membentuk karakter siswa itu sendiri. Perilaku dan tindakan siswa itu sendiri pun masih kental dengan budaya lokalnya. Namun kondisi ini hanya terjadi di Sekolah Menengah Atas (SMA) Negeri, sedangkan swasta seperti kehilangan identitas budaya lokalnya. Respon siswa terhadap materi sejarah lokal Kraton Buton di kelas cukup baik. Akan tetapi, hal ini hanya terjadi di sekolah-sekolah negeri saja, sedangkan di sekolah swasta, respon siswa tersebut mulai hilang dalam pembelajaran sejarah lokalnya.

SMA Negeri 4 dan 6 Baubau, memiliki siswa yang mempunyai daya tarik belajar sangat tinggi. Bahkan dalam penyampaian materi sejarah di dalam kelas siswa cukup antusias dalam mengikuti pembelajaran sejarah tersebut. Guru sejarah juga mampu mengaitkan sejarah lokal Kraton Buton dengan sejarah nasional. Siswa sangat aktif dalam merespon pembelajaran sejarah lokal ini. Alasannya ialah guru sering mengajak mereka untuk berkunjung ke Kraton Buton dan ada juga atas dasar keinginan dan kemauan sendiri siswa membuat kelompok untuk berkunjung ke Kraton Buton dalam mencari berbagai informasi.

Fenomena yang berbeda terjadi di SMA Swasta Bataraguru Baubau, materi sejarah nasional yang dipadukan dengan sejarah lokal yang disampaikan oleh guru sejarah di kelas kurang mendapatkan respon dari siswa. Hal ini dikarenakan minat belajar siswa disekolah ini kurang baik, 
sehingga pembelajaran sejarah di kelas pun tidak berjalan dengan baik. Kondisi ini merupakan kurangnya kesadaran siswa mengenai pentingnya pembelajaran sejarah lokal

\section{KESIMPULAN}

Berdasarkan peraturan Pemerintah Kota Baubau No. 105 tahun 2003 tentang kawasan Kraton Buton yang masuk area khusus, maka melalui Dinas Pariwisata dilakukan berbagai macam upaya untuk melestarikan wilayah Kraton Buton agar dapat dijadikan sebagai sumber sejarah lokal. Upaya tersebut berupa perbaikan dan pemugaran benteng kraton, perbaikan situs-situs sejarah, penataan ruang wilayah kraton dan pelestarian budaya kesultanan Buton. Upaya ini juga kemudian mengundang reaksi para guru dan siswa untuk memanfaatkan Kraton Buton sebagai sumber sejarah local dalam pembelajaran sejarah di kelas.

Pemanfaatan tersebut melalui pengumpulan sumber fisik dan sumber tertulis. Pemanfaatan Sumber fisik berupa bangunan-bangunan kuno, benteng yang mengelilingi kraton, makam-makam sultan, gua persembunyian Raja Bone yang bernama Arung Palaka pada saat melarikan diri di Kraton Buton dan benda-benda antik lainnya. Sumber tertulis yang dimanfaatkan oleh guru sejarah berupa buku sejarah Buton yang tersimpan di perpustakaan pribadi A. M. Zahari, jurnal tata kota yang diterbitkan oleh Dinas Pariwisata dan informasi yang didapat dari masyarakat adat Kraton Buton. Selain itu guru, siswa juga memanfaatkan Kraton sebagai sumber belajar sejarah, sehingga siswa memberikan respon cukup beragam. 
Bagi sekolah yang berstatus negeri respon siswa cukup baik dan meyakinkan, karena munculnya kesadaran siswa itu sendiri dan pengarahan guru sejarah yang baik terhadap materi sejarah lokal di kelas sedangkan pada sekolah swasta masih jauh yang diharapkan, karena kurangnya perhatian siswa terhadap pembelajaran sejarah dan keenggenan guru sejarah dalam merancang pembelajaran sejarah dengan memadukan materi sejarah lokal di kelas.

\section{DAFTAR PUSTAKA}

[1] Al-Tabany, Trianto I. B. (2014). Mendesain Model Pembelajaran Inovatif, Progresif dan Kontekstual. Jakarta: Prenada Media.

[2] Gunning, Dennis. (1978). The Teaching of History. London: Longmand.

[3] Kartodirdjo, Sartono. (2014).Pendekatan Ilmu Sosial dalam Metodologi Sejarah. Yogyakarta: Ombak Dua.

[4] Suryanegara, Ahmad. (2008). Api Sejarah. Bandung: Pustaka Semesta.

[5] Widja, I. Gde. (2012).Pengantar Ilmu Sejarah: Sejarah dalam Perspektif Pendidikan. Semarang: Satya Wacana. 